Estimating the Consumption and Investment Demands for Housing and Their Effect on Housing Tenure Status

Author(s): Yannis M. Ioannides and Stuart S. Rosenthal

Source: The Review of Economics and Statistics, Vol. 76, No. 1 (Feb., 1994), pp. 127-141

Published by: The MIT Press

Stable URL: http://www.jstor.org/stable/2109831

Accessed: 19/02/2014 15:48

Your use of the JSTOR archive indicates your acceptance of the Terms \& Conditions of Use, available at

http://www.jstor.org/page/info/about/policies/terms.jsp

JSTOR is a not-for-profit service that helps scholars, researchers, and students discover, use, and build upon a wide range of content in a trusted digital archive. We use information technology and tools to increase productivity and facilitate new forms of scholarship. For more information about JSTOR, please contact support@jstor.org. 


\title{
ESTIMATING THE CONSUMPTION AND INVESTMENT DEMANDS FOR HOUSING AND THEIR EFFECT ON HOUSING TENURE STATUS
}

\author{
Yannis M. Ioannides and Stuart S. Rosenthal*
}

\begin{abstract}
Theoretical work suggests that families live in owner-occupied housing if their investment demand for housing exceeds their consumption demand for housing. Using household data from the 1983 Survey of Consumer Finances, we test this theory by estimating an ordered probit model of whether families rent without owning property, rent while owning property other than their home, own their home without owning other properties, or own their home in addition to other properties. For owner-occupiers who own additional property, both the investment and consumption demands are directly observed enabling us to separately identify these functions.

Results suggest that investment demand is more sensitive to wealth and income than is consumption demand, but that consumption demand is more sensitive to demographic variables and proximity to urban suburbs. In addition, test results indicate that the principal residence of most owner-occupiers is determined by their consumption demand for housing, not their investment demand. Hence, previous empirical housing demand studies likely to have identified the consumption demand for housing. Test results also suggest that, although the divergence between investment and consumption demand for housing is an important determinant of housing subtenure status, other factors also influence housing tenure decisions.
\end{abstract}

\section{Introduction}

$\mathrm{T}$ HEORETICAL work by Henderson and Ioannides (1983) suggests that in the absence of tax distortions, borrowing constraints, and transactions costs, the decision to own a home is driven by the divergence between the investment $\left(H_{I}\right)$ and consumption $\left(H_{C}\right)$ demands for housing (see also Fu (1991)). Specifically, families live in owner-occupied housing if $H_{I}$ exceeds $H_{C}$, where $H_{I}$ reflects portfolio motives and $H_{C}$ reflects

Received for publication March 5, 1992. Revision accepted for publication August 9, 1993.

* Virginia Polytechnic Institute and State University and University of British Columbia, respectively.

We are grateful to Robert Avery and Arthur Kinnickell for giving us access to their cleaned data tape of the 1983 Survey of Consumer Finances. We also thank Robert Moffitt and two anonymous referees for their constructive comments on an earlier version of the paper. Ioannides acknowledges partial research support by National Science Foundation Grant SES9000200. Rosenthal acknowledges support from the Social Science and Humanities Research Council of Canada (grant number 410-92-1261) and the Real Estate Institute of British Columbia. preferences for housing services. ${ }^{1}$ Previous empirical studies of housing demand and tenure choice, however, fail to distinguish $H_{I}$ from $H_{C}$, or to model the linkage between $H_{I}, H_{C}$, and housing tenure. $^{2}$

This paper estimates a model which separately identifies $H_{I}$ and $H_{C}$ by simultaneously distinguishing four housing "subtenures." Families can rent without owning property (Rent 1 ), rent while owning property other than their home (Rent2), own their home without owning other properties $(O w n 1)$, or own their home in addition to other properties $(\mathrm{Own} 2)$. Provided the assumptions underlying the Henderson and Ioannides (1983) model are met, choice of housing subtenure is based on an index $(J)$ equal to the excess of the investment demand over the consumption demand for housing, $H_{I}$ and $H_{C}$. As $J$ exceeds a series of thresholds, families successively change subtenures from Rent1 to Own2. In addition, for Own 2 households, $H_{I}$ and $H_{C}$, in principle, can be observed since $H_{C}$ is the principal residence, while $H_{I}$ equals total property holdings (including the principal residence). Hence, a maximum likelihood model can be specified which simultaneously identifies the threshold values and the determinants of both $H_{I}$ and $H_{C}$ (even though

\footnotetext{
${ }^{1}$ As will become apparent later in the paper, in the context of our work here, we could refer to $H_{I}$ as the investment demand for real estate, not just housing. However, we refer to $H_{I}$ as the investment demand for housing throughout the paper, in part to avoid confusion when discussing the determinants of housing tenure choice, and also to remain consistent with previous literature.

${ }^{2}$ Instead, various housing studies have highlighted the role of tax effects (Rosen (1979)), borrowing constraints (Duca and Rosenthal (forthcoming) and Zorn (1989)), and transactions costs (Venti and Wise (1984) and Goodman (1990)) without attempting to address the distinction between the investment and consumption demands for housing. (For excellent reviews of previous studies of housing demand and tenure choice see Rosen (1985) and Olsen (1986)). Moreover, although Henderson and Ioannides (1987) draw on implications of their earlier (1983) study when using the Panel Study of Income Dynamics (PSID) to examine housing tenure, the PSID data do not enable them to explicitly identify the investment and consumption demands for housing.
} 
$H_{I}$ and $H_{C}$ are not observed for some households). This model can also be generalized to allow for the effect of tax distortions and the like by omitting the distinction between Rent 1 and Rent 2 families and focusing on the divergence that would arise between $H_{I}$ and $H_{C}$ when families face the budget space enjoyed by owneroccupiers (in a manner to be clarified below).

The study is based on the 1983 Survey of Consumer Finances (SCF) which includes detailed information on the household's balance sheet and socio-demographic characteristics, and allows us to divide households into the housing subtenures noted above. Our results confirm that for owner-occupiers the consumption demand for housing differs from investment demand. We show that $H_{I}$ is more sensitive to wealth and income than is $H_{C}$, but that $H_{C}$ is more sensitive to age, education, family size, and proximity to urban suburbs. In addition, test results indicate that the value of the principal residence of most owner-occupiers is determined by their consumption demand for housing, not their investment demand. Hence, previous empirical housing demand studies likely have identified the consumption demand for housing. Our findings also provide support for the divergence between $H_{I}$ and $H_{C}$ as an important determinant of housing tensure status.

The paper proceeds as follows. The following section describes the underlying behavioral model, section III describes the empirical framework and tests of the model structure, section IV presents the data, section $\mathrm{V}$ presents our results, and section VI is reserved for concluding comments.

\section{The Behavioral Model}

Housing stock is assumed to be homogeneous and may be owned for investment purposes, or owned and occupied, thus being used for both consumption and investment purposes. Household $i$ has a consumption demand for housing stock (derived from the consumption demand for housing services), and an investment demand for housing stock based on portfolio motives, $H_{C i}=$ $H_{C}\left(X_{i}, e_{C i}\right)$ and $H_{I i}=H_{I}\left(X_{i}, e_{I i}\right)$, respectively. ${ }^{3}$

\footnotetext{
${ }^{3}$ Henderson and Ioannides (1983) show that both $H_{I}$ and $H_{C}$ are generated from the family's lifetime utility maximization problem. $H_{I}$, in particular, satisfies the usual portfolio condition of equating risk adjusted rates of return across assets.
}

$X$ is a vector of explanatory variables (defined, for simplicity, as the union of all determinants of the elements common to both the investment and consumption functions), while $e_{C i}$ and $e_{I i}$ are random errors which may be correlated (since $H_{C}$ and $H_{I}$ are jointly determined from a life cycle model). $H_{C}$ is restricted to be positive by the behavior model, while $H_{I}$ is nonnegative under the assumption that short holdings of housing stock are not allowed.

Henderson and Ioannides (1983) propose that in the absence of tax distortions, borrowing constraints, and transactions costs, the decision to rent versus to own may be viewed in terms of the divergence between the desired amount of housing stock for consumption and for investment purposes. If $H_{C}$ is sufficiently larger than $H_{I}$, a household is better off renting. If $H_{C}$ exceeds $H_{I}$ by only a small amount, families which are good at maintaining their property may distort their investment demand and own $H_{C}$. By doing so, such families avoid externalities in the rental market which cause households with a predisposition to take good care of a rental property to implicitly subsidize the rental cost of other households. ${ }^{4}$ Similarly, if a household's investment demand exceeds consumption demand, that household is better off owner-occupying an amount of housing stock equal to $H_{C}$ and holding for portfolio purposes additional property equal to $H_{I}-$ $H_{C}$.

The arguments above suggest that in the absence of transactions costs and institutional constraints, the principal residence of owneroccupants is determined primarily by their consumption demand (regardless of whether $H_{I}$ is less than or greater than $H_{C}$ ). Suppose, however, that there are lump sum costs associated with the purchase of real estate, or institutional constraints that restrict the minimum size of properties which can be purchased. If $H_{I}$ exceeds $H_{C}$ by a small amount (relative to the lump sum

\footnotetext{
${ }^{4}$ Henderson and Ioannides (1983) argue that because of limited information, landlords cannot distinguish, ex ante, good tenants from bad tenants. Under such circumstances, landlords charge rents which reflect average maintenance costs across potential tenants. It follows that tenants who have a predisposition to maintain their home pay rents which exceed the marginal costs they impose on landlords. The reverse holds for tenants which tend not to maintain their residence.
} 
Figure 1.-Housing Subtenure Choice

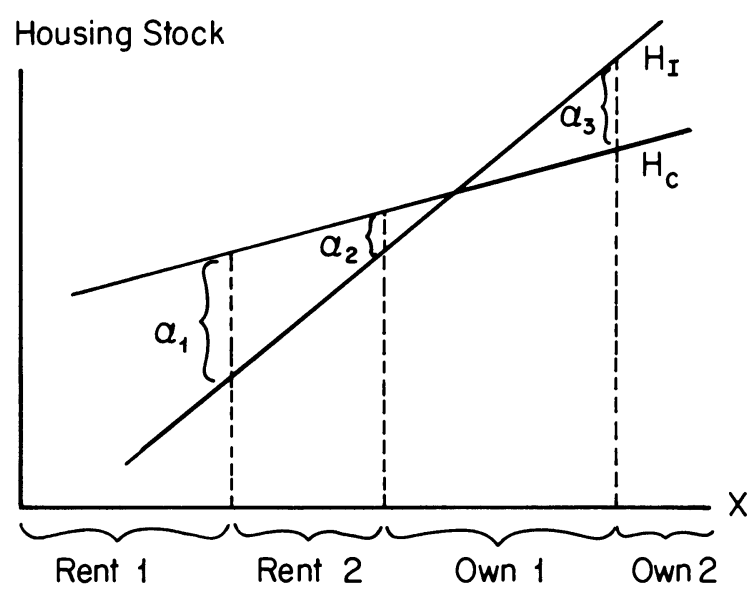

costs of purchasing additional property), it is possible that the level of housing held for consumption by owner-occupiers could equal investment demand for a much greater portion of households than strict equality of $H_{C}$ and $H_{I}$ would justify. Given that almost all empirical studies of housing demand to date emphasize the principal residence of owner-occupiers, it is desirable to understand whether such studies actually identify the investment or consumption demand for housing, or a combination of the two demands.

Figure 1 clarifies these arguments. The horizontal axis indicates $X$ (the systematic determinants of $H_{I}$ and $H_{C}$ ), which is defined such that an increase in $X$ leads to an increase in both the investment and consumption demands, respectively, while the vertical axis indicates housing stock. $^{5}$ In the region Rent 1 , observe that $H_{C}$ exceeds $H_{I}$. In addition, we assume that investment demand is sufficiently low that families do not want to hold real estate in portfolio (either because households cannot go short in real estate or because transactions costs outweigh the benefit of holding property). The household, therefore, rents $H_{C}$ and holds no housing for investment purposes. In the region Rent2, a household still rents $H_{C}$ but also holds housing stock in its

\footnotetext{
${ }^{5}$ Figure 1 is drawn with $X$ on the horizontal axis to help clarify the intuition behind our model of housing subtenure choice. We should emphasize, however, that housing subtenure choice does not depend on individual elements of $X$, but instead relies on the divergence between $H_{I}$ and $H_{C}$. A precise algebraic description of the arguments above as they relate to our empirical model is given in expression (4.1-4.4) in the following section.
}

portfolio, $H_{I}$. In the region $O w n 1$, households find it advantageous to owner-occupy an amount of housing stock which is possibly different from either the consumption demand or the investment demand. Finally, in the region Own2, a household owner-occupies an amount of housing equal to its consumption demand, $H_{C}$, and holds an additional amount of housing stock in portfolio equal to the difference between $H_{I}$ and $H_{C}$.

Define the difference between $H_{I}$ and $H_{C}$ as $J$, and $\alpha_{1}, \alpha_{2}$, and $\alpha_{3}$ as the set of critical values for $J$ which determine transition from Rent1 to Rent2, Rent 2 to $O w n 1$, and $O w n 1$ to $O w n 2$, respectively (as in figure 1). Observe that $\alpha_{1}<\alpha_{2}$ $<\alpha_{3}$ (consistent with arguments above), which says that as the difference between the investment and consumption demands for housing increases, households switch successively from housing "subtenure" Rent 1 to $O w n 2$. In addition, if households rent only when $H_{C}$ exceeds $H_{I}, \alpha_{1}$ and $\alpha_{2}$ would be negative, while $\alpha_{3}$ would be positive if families own only when $H_{I}$ is greater than or equal to $H_{C}$.

\section{Tax Incentives, Borrowing Constraints, and Transactions Costs}

Suppose now that favorable tax treatment and transactions costs cause the rate of return on owner-occupied housing to differ from the rate of return on real estate holdings other than the principle residence. ${ }^{6}$ In addition, suppose that such effects influence the willingness of lenders to finance a family's principal residence versus other real estate investments. Then the household's budget constraint and real estate investment opportunities will differ depending on whether families rent their principal residence or become owner-occupiers. This is in contrast to the model above which implicitly assumes that renters and owner-occupiers face the same budget constraint and investment opportunities.

Under these conditions the divergence between $H_{I}$ and $H_{C}$-as determined based on the budget constraint of owner-occupiers-would not be a good predictor of whether renters do or do not own real estate because the Rent $1 /$ Rent 2 sub-

\footnotetext{
${ }^{6}$ Homeowners, for example, are not taxed on imputed rent in contrast to landlords. Also, the transactions costs of selling an owner-occupied home are substantially higher than for other real estate holdings since homeowners must move when they sell their homes.
} 
tenure decision is based on a different set of budget conditions. On the other hand, note that the budget constraint and investment opportunities of $O w n 1$ and $O w n 2$ families are similar since both groups own their principal residence. Consider then the divergence between $H_{I}$ and $H_{C}$, where $H_{I}$ and $H_{C}$ are determined based on the budget constraint of owner-occupiers. If $H_{I}$ is sufficiently less than $H_{C}$, then as before families would choose to rent since the level of owneroccupied housing required to satisfy the family's consumption needs would constitute a bad investment. Similarly, if $H_{I}$ exceeds $H_{C}$ by a small amount families would own only their principal residence $(O w n 1)$, while if $H_{l}$ exceeds $H_{C}$ by a large amount families would own both their principal home and additional real estate (Own2). Hence, allowing for tax effects, borrowing constraints, and transactions costs, the divergence between $H_{I}$ and $H_{C}$-based on the budget constraint of owner-occupiers-determines whether families choose to become renters, $O w n 1$, or Own 2 households. $^{7}$

\section{The Econometric Model}

Consider first the case when the budget space of owner-occupiers and renters is similar. Then the ordinal ranking of housing subtenure based on the difference between the investment $\left(H_{I}\right)$ and consumption $\left(H_{C}\right)$ demands for housing (denoted by $J$ ) suggests that an ordered discrete choice model could be used to evaluate choice of housing subtenure. In addition, because $J$ itself is the difference between $H_{I}$ and $H_{C}$, and $H_{I}$ and $H_{C}$ are directly observed for the subsample consisting of $O w n 2$ households, in principle, a maximum likelihood model could be estimated which identifies the investment and consumption functions while simultaneously determining housing subtenure.

\footnotetext{
${ }^{7}$ Given that owner-occupiers and renters face different budget constraints, in principle one could argue that even if $H_{I}$ is substantially less than $H_{C}$-where $H_{I}$ and $H_{C}$ are determined based on the budget constraint of owner-occupiers-a family might still prefer to own its principal residence if the unit cost of renting were sufficiently high. In practice, however, such an argument would generally not hold because the rate of return on owner-occupied housing increases with the cost of renting given that owner-occupiers do not have to pay rental fees. A similar argument ensures that if $H_{I}$ exceeds $H_{C}$ (given the budget constraint of owner-occupiers) then families will choose to own their homes.
}

Formally, we present our empirical model by defining the investment demand for housing,

$$
H_{I i}=X_{i} b_{I}+e_{I i}
$$

and the consumption demand for housing,

$$
H_{C l}=X_{\imath} b_{C}+e_{C i} \text {. }
$$

It is useful to also define the difference between $H_{I i}$ and $H_{C i}$,

$$
\begin{aligned}
J_{\imath} & \equiv H_{I i}-H_{C i} \\
& =X_{i}\left(b_{I}-b_{C}\right)+e_{I l}-e_{C i} \\
& =X_{i} g+w_{l},
\end{aligned}
$$

where $g \equiv b_{I}-b_{C}$, and $w_{\iota} \equiv e_{I t}-e_{C i}$. Both $H_{C}$ and $H_{I}$ are interpreted in $\log$ form for the remainder of the paper. Hence, $J$ and the parameters $\alpha_{1}, \alpha_{2}$, and $\alpha_{3}$ introduced below reflect the percentage difference between investment and consumption demands for housing. ${ }^{8}$

Housing subtenure is determined by,

$$
\begin{aligned}
-\infty<J_{i}<\alpha_{1} & \Rightarrow-\infty<w_{i}<\alpha_{1}-X_{i} g \\
& \Rightarrow \text { Rent1 } \\
\alpha_{1}<J_{i}<\alpha_{2} & \Rightarrow \alpha_{1}-X_{i} g<w_{i}<\alpha_{2}-X_{i} g \\
& \Rightarrow \text { Rent } 2 \\
\alpha_{2}<J_{i}<\alpha_{3} & \Rightarrow \alpha_{2}-X_{i} g<w_{i}<\alpha_{3}-X_{i} g \\
& \Rightarrow \text { Own1 } \\
\alpha_{3}<J_{i}<\infty & \Rightarrow \alpha_{3}-X_{i} g<w_{i}<\infty \\
& \Rightarrow \text { Own } 2,
\end{aligned}
$$

where (4.1) through (4.4) reflect the ordinal ranking of subtenures implied by Henderson and Ioannides (1983) (figure 1).

Under the assumption that $e_{I i}$ and $e_{C i}$ obey a bivariate normal distribution, $w_{i}$ also is distributed normal with variance $\sigma_{w}^{2}=\sigma_{I}^{2}+\sigma_{C}^{2}-$ $2 \sigma_{I C}$. Consistent estimates of $g / \sigma_{w}, \alpha_{1} / \sigma_{w}$, $\alpha_{2} / \sigma_{w}$, and $\alpha_{3} / \sigma_{w}$ can be obtained based on an ordered probit procedure. The log-likelihood

\footnotetext{
${ }^{8}$ Although families in the region Rent1 (in figure 1) hold zero housing in portfolio, we can express $H_{I}$ in log form under the assumption that transactions costs and institutional constraints impose a floor on the minimum positive level of real estate an individual can hold in portfolio. Hence, investment demand can lie between zero and the floor (enabling us to express $H_{I}$ in log form), but families choose to hold zero property. The censoring mechanism which governs when families choose to hold zero real estate in portfolio is, in principle, governed by the difference between $H_{I}$ and $H_{C}$ as reflected in our empirical model.
} 
function for the ordered probit model is given by

$$
\begin{array}{r}
L=\sum_{i}\left\{\text { rent } 1_{i} \cdot \log \left\{F\left(\alpha_{1} / \sigma_{w}-X_{i} g / \sigma_{w}\right)\right\}\right. \\
+ \text { rent } 2_{i} \cdot \log \left\{F\left(\alpha_{2} / \sigma_{w}-X_{i} g / \sigma_{w}\right)\right. \\
\left.-F\left(\alpha_{1} / \sigma_{w}-X_{i} g / \sigma_{w}\right)\right\} \\
+ \text { own } 1_{i} \cdot \log \left\{F\left(\alpha_{3} / \sigma_{w}-X_{i} g / \sigma_{w}\right)\right. \\
\left.-F\left(\alpha_{2} / \sigma_{w}-X_{i} g / \sigma_{w}\right)\right\} \\
\left.+ \text { own } 2_{i} \cdot \log \left\{1-F\left(\alpha_{3} / \sigma_{w}-X_{i} g / \sigma_{w}\right)\right\}\right\},
\end{array}
$$

where the constant in $X$ is normalized to zero, $F$ is the standard normal distribution function, and the dependent variables indicating the household's subtenure, Rent1, Rent 2, Own1, and Own2, are 1-0 variables which sum to 1 for each family.

Under the null hypothesis that the econometric model (4.1-4.4) correctly characterizes the choice of housing subtenure, and that $w$ is distributed normal, a "coarser" version of the subtenure choice model is also estimable. Specifically, note that the probability of observing an Own 2 household is,

$$
\begin{aligned}
\operatorname{Pr}\left[J_{i}\right. & \left.>\alpha_{3}\right] \\
& =\operatorname{Pr}\left[w / \sigma_{w}<-\alpha_{3} / \sigma_{w}+X_{i} g_{1} / \sigma_{w}\right],
\end{aligned}
$$

the probability of observing an owner-occupier $(O w n 2$ or $O w n 1)$ is,

$$
\begin{aligned}
\operatorname{Pr}\left[J_{i}\right. & \left.>\alpha_{2}\right] \\
& =\operatorname{PR}\left[w / \sigma_{w}<-\alpha_{2} / \sigma_{w}+X_{i} g_{2} / \sigma_{w}\right],
\end{aligned}
$$

and the probability of observing someone other than a Rent1 family (Rent2, Own2, or $O w n 1)$ is,

$$
\begin{aligned}
\operatorname{Pr}\left[J_{i}\right. & \left.>\alpha_{1}\right] \\
& =\operatorname{Pr}\left[w / \sigma_{w}<-\alpha_{1} / \sigma_{w}+X_{i} g_{3} / \sigma_{w}\right] .
\end{aligned}
$$

Equations (6.1-6.3) are each estimable by maximum likelihood probit and yield consistent, but inefficient, estimates of all of the parameters of the ordered probit model under the null hypothesis. Note, however, that the slope parameters in (6.1-6.3) are not constrained to be equal across the three probit equations. Hence, under the alternative hypothesis that (4.1-4.4) do not correctly characterize choice of housing subtenure, the parameters in (6.1-6.3) still are consistent but would likely differ from estimates obtained from the ordered probit method.

Under these conditions a Hausman test can be used to evaluate the model structure implied by
(4.1-4.4). The test statistic is given by,

$$
T=\sum_{k}^{3}\left(q_{o k}-q_{s k}\right)^{\prime}\left[V_{o k}-V_{s k}\right]^{-1}\left(q_{o k}-q_{s k}\right),
$$

where $k=\{1,2,3\}$, for each of the three probit models in (6), $q$ are parameters from the ordered $(o)$ probit and single $(s)$ probit models (where the appropriate $\alpha$ is included in $q_{o k}$ ), and $V_{o k}$ and $V_{s k}$ are the corresponding covariance matrices. If the model structure is correct, $T$ is asymptotically distributed Chi-square (with degrees of freedom equal to the total number of restrictions).

Consider now the case in which the budget spaces of owner-occupiers and renters differ because of tax advantages, borrowing constraints, and transactions costs. As discussed earlier, under those conditions, the divergence between $H_{I}$ and $H_{C}$-given the budget space of owneroccupiers-determines whether families become renters, Own1, or Own2 households. Accordingly, a three-celled ordered probit model can be estimated to evaluate the choice of Rent, Own1, and $O w n 2$, results from which can be compared to estimates from the separate $O w n 2$ and $O w n$ (Own1 or Own2) probit models defined by expressions (6.3) and (6.2).

It is also desirable to identify the investment and consumption demands for housing, and to compare these functions to the housing decisions of Own1 families (referred to as the "mixed" demand function) and to a regression based on the principal residence of all owner-occupiers as estimated in previous studies (referred to as the "traditional" demand function). Consistent estimation of each of these functions may be based on traditional 2-step methods designed to control for selection effects. Given that both $H_{I}$ and $H_{C}$ are observed only for Own2 households, a Mills ratio is constructed based on the Own2 probit model ((6.3)). The Mills ratio is then included in second stage ordinary least squares regressions of (1) and (2) using only Own2 families (correcting standard errors for selection effects). ${ }^{9}$ An analogous procedure is used to estimate the mixed and

\footnotetext{
${ }^{9}$ If (4.1) and (4.4) are correct, the coefficients on the Mills ratio $(f)$ for the investment and consumption functions equal,

$$
\begin{aligned}
& f=\operatorname{Cov}\left(e_{I}, w\right) / \sigma_{w}=\left(\sigma_{I}^{2}-\sigma_{I C}\right) / \sigma_{w}, \\
& f=\operatorname{Cov}\left(e_{C}, w\right) / \sigma_{w}=\left(\sigma_{I C}-\sigma_{C}^{2}\right) / \sigma_{w},
\end{aligned}
$$
}

respectively, where $\sigma_{I}^{2}, \sigma_{C}^{2}$, and $\sigma_{I C}$ are the covariance parameters from (1) and (2) and $\sigma_{w}$ is defined as before. 
traditional demand functions, where the first stage probits evaluate whether families become $O W N 1$ households or owner-occupiers $(O W N 1$ or $O W N 2$ ), respectively.

If Own1 families choose their residence based on their consumption demand (as opposed to their investment demand), the traditional housing demand function yields consistent estimates of the consumption demand for housing, and is more efficient than estimates obtained based only on Own2 families since more data are used. If, however, Own1 housing is influenced by portfolio motives, the traditional demand function is an inconsistent estimate of the housing consumption function, though the Own2 (selection corrected) estimate of the consumption function still is consistent. A Hausman specification test between the consumption function estimated over $O w n 2$ families versus the traditional demand function enables us to evaluate the null that $O w n 1$ housing is determined primarily by housing consumption demand as opposed to portfolio motives. ${ }^{10}$

Finally, observe that under the null hypothesis that (4.1-4.4) correctly characterize housing subtenure choice, estimates of the covariance parameters $\sigma_{I}, \sigma_{C}$, and $\sigma_{I C}$ (obtained from the investment and consumption functions) can be used to obtain an initial consistent estimate of $\sigma_{w}$ as $\left(\sigma_{I}^{2}+\sigma_{C}^{2}-2 \sigma_{I C}\right)^{1 / 2}$. By maximum likelihood estimation according to (5) we can then obtain initial consistent estimates of $\alpha_{1}, \alpha_{2}$, and $\alpha_{3}$. In principle, these initial consistent estimates could be used as starting values in a likelihood function which simultaneously identifies $H_{I}, H_{C}$, and housing subtenure choice. Unfortunately, the likelihood function for the complete model, presented in appendix A, did not converge regardless of whether families were allowed to choose

\footnotetext{
${ }^{10}$ We also estimated $O w n 1$ housing consumption directly by controlling for selection effects through a first stage probit model on Own1. Test results comparing the Own1 housing function to the Own2 consumption function are essentially identical to those obtained based on the procedure described above and are presented later in the paper. We should note, however, that under the null that (4.1-4.4) are correct, although the "traditional" selection model can be based on a probit model (of whether families own or rent), the probability of observing an Own1 family should not be estimated by probit since the underlying error term has a doubly truncated normal distribution. Under the alternative, that (4.1-4.4) are not correct, in principle both the $O w n 1$ and traditional probit based selection models could be acceptable. Nevertheless, the test procedure described in the text is more robust than the Ownl selection model and is preferred for that reason.
}

between three or four housing subtenures (a possible explanation for this result is provided later in the paper).

\section{Data and Variables}

The main data source for the study is the 1983 Survey of Consumer Finances (SCF) which contains 4303 households. From these households we excluded any observations with relevant missing values, families with wealth over one million dollars (1983 dollars) and households which belong to the high income subsample in the SCF (Avery and Elliehausen (1988)). The remaining sample of 3,569 households is representative of United States households in 1983. Variable definitions and summary statistics for the data used in the analysis are provided in appendix B.

A key strength of the 1983 SCF which makes it uniquely suitable for the present study is the tremendous detail provided on the household's balance sheet, including information about whether families own property other than their principal residence. That detail makes it possible to split families into the four subtenures, Rent1, Rent2, Own1, and Own2, as defined earlier. Log of the house value of the principal residence was then used as the dependent variable in the housing consumption, Own1 ("mixed"), and "traditional" demand functions, while log of the total value of all real estate holdings (including the principal residence) was the dependent variable for the investment function.

Turning to the explanatory variables in the model, results from Henderson and Ioannides (1983) in conjunction with Fu (1991) suggest that, a priori, wealth has an ambiguous effect on housing tenure preferences (where wealth is formed here as the difference between non-pension assets and debt). ${ }^{11}$ Note also, that housing subtenure status could influence the observed level of wealth held by a family, particularly given the rapid increase in home prices just prior to our sample period. To control for possible simultaneity effects, wealth (in $\$ 100,000$ units) is regressed on all of the exogenous variables in the model as

\footnotetext{
${ }^{11}$ Building off of Henderson and Ioannides (1983), Fu (1991) shows that both the investment and consumption demands for housing increase with wealth, which suggests that wealth has an ambiguous effect, a priori, on housing subtenure preferences.
} 
well as some additional variables taken from the SCF. For families with positive fitted wealth values, the $\log$ of the fitted value (WHAT) was included as a regressor. In addition, roughly fourteen percent of the sample had negative fitted wealth values, consistent with the actual percentage of the sample with negative net worth. For families with negative fitted wealth values, WHAT was set equal to $-\log [a b s(\hat{w})]$, where $a b s(\hat{w})$ is the absolute value of the original fitted value from the wealth regression. ${ }^{12}$ Results from the wealth regression are provided Ioannides and Rosenthal (1991).

Apart from wealth, most of the variables commonly used in housing demand and tenure choice studies are included in the model. The log of total current household pretax income (LINC) measured in $\$ 100,000$ units was included, and proxies both the effect of income on preferences as well as tax effects. ${ }^{13}$ Tax-related price effects were further proxied by the log of the household's Federal marginal income tax rate $(L M T) .{ }^{14}$ The relative cost of owning to renting may also vary across households because of regional differences in expected capital gains. These effects were proxied using county-wide data from the 1980 decennial census. For each household in our sample we formed the county-wide ratio of the median house value of owners to the median monthly

\footnotetext{
${ }^{12}$ We also estimated the entire model setting $W H A T$ equal to $\log [a b s(\hat{w})]$ for all families and including a second regressor, Neg $\cdot \log [a b s(\hat{w})]$ to control for observations with negative fitted wealth values (where $\mathrm{Neg}$ equals 1 if $\hat{w}$ is negative and 0 otherwise). Results from both methods were quite similar causing us to favor the simpler procedure described above.

${ }^{13}$ Federal tax laws allow homeowners to deduct mortgage interest and property tax payments (although maintenance expenses are not deductible), while imputed rent is not taxed (see Rosen (1979), for example). The value of these tax provisions is sensitive to income through the marginal income tax rate.

${ }_{14}$ Marginal income tax rates $(M T)$ were obtained by first running regressions using a random sample of U.S. income tax returns obtained from the IRS (Internal Revenue Service) to determine taxable income in tax year 1982 based on variables common both to the 1982 IRS and 1983 SCF data (which pertain to 1982 household income). Coefficients from the IRS regressions were then used to predict 1982 taxable income for each family in the sample and marginal tax rates were determined based on the tax tables for 1982 and the family's tax status. For families with zero values for $M T, M T$ was set equal to 0.01 when taking logs for $L M T$. In contrast to this procedure, most previous studies using the SCF data ignore marginal income tax rates because the $S C F$ does not report reliable measures of $M T$.
}

rent of renters; the log of that ratio ( $L H V R N T)$ is entered in the model. In general, one would expect $L H V R N T$ to be larger in regions with higher expected housing price inflation, as expected capital gains are capitalized into higher house values but reduce equilibrium rental rates.

Under the assumption that housing prices vary with population density and size, price effects are further captured by a series of 1-0 dummy variables which describe proximity to densely populated areas. These variables include $C C B I G$ (1 if in the central cities of the ten largest SMSAs), CCOTHER ( 1 if in the central cities of other SMSAs), SUBBIG (1 if in an urbanized area of the ten largest SMSAs, but not in the central city), SUBOTHER (1 if in the suburbs of other SMSAs), and FARSUB (1 if outside the suburban belt but within 50 miles of a central business district of a central city). The omitted category is rural areas which comprise roughly $20 \%$ of the sample.

A number of demographic variables also were used as regressors. These variables include age of the household head ( $A G E), A G E$ squared ( $A G E S Q$ ), education of the household head [ $E D$ (1 if high school or more)], sex of the household head [SEX (1 if male)], race of the household head [RACE (1 if nonwhite)], marital status [MARR (1 if married)], and household size (HSIZE). We also attempted to control directly for the potential effect of borrowing constraints on housing demand and subtenure choice by including three variables frequently requested on loan application forms. These variables are the number of years the household head has worked at the current employer (CUREMP), whether the household has received public assistance [WELFARE (1 if yes)], and whether the household has had problems making loan payments in the past three years [BADHST (1 if yes)]. ${ }^{15}$

\section{Results}

Results from the 4-celled ordered probit, 3celled ordered probit, Rent1, Own (Own1+ Own2), and Own2 probit models are presented in

\footnotetext{
${ }^{15}$ Several studies confirm that time at the current job, credit history, and the receipt of welfare payments are important determinants of who is credit constrained (see, for example, Munnell et al. (1992), Duca and Rosenthal (1993), Jappelli (1990), and Boyes, Hoffman and Lowe (1989)).
} 
Table 1.-Model Test Based on Ordered and Single Probit Parameter Values (numbers in parentheses are $t$-ratios)

\begin{tabular}{|c|c|c|c|c|c|}
\hline Variable & $\begin{array}{l}\text { 4-Celled } \\
\text { Ordered } \\
\text { Probit }\end{array}$ & $\begin{array}{l}\text { 3-Celled } \\
\text { Ordered } \\
\text { Probit }\end{array}$ & $\begin{array}{l}\text { Rent 1 } \\
\text { Probit }\end{array}$ & $\begin{array}{l}\text { Own } \\
\text { Probit }\end{array}$ & $\begin{array}{l}\text { Own2 } \\
\text { Probit }\end{array}$ \\
\hline$\alpha_{1}$ & $\begin{array}{c}-1.0122 \\
(-1.9046)\end{array}$ & - & $\begin{array}{l}-1.69866 \\
(-2.4694)\end{array}$ & - & - \\
\hline$\alpha_{2}$ & $\begin{array}{l}-0.89671 \\
(-1.6873)\end{array}$ & $\begin{array}{r}-.93774 \\
(-1.7411)\end{array}$ & - & $\begin{array}{l}-1.83074 \\
(-2.6656)\end{array}$ & - \\
\hline$\alpha_{3}$ & $\begin{array}{c}0.95617 \\
(1.7952)\end{array}$ & $\begin{array}{c}0.91676 \\
(1.6942)\end{array}$ & - & - & $\begin{array}{c}1.9624 \\
(2.4566)\end{array}$ \\
\hline WHAT & $\begin{array}{c}0.03058 \\
(1.6488)\end{array}$ & $\begin{array}{c}0.02980 \\
(1.5531)\end{array}$ & $\begin{array}{l}0.037224 \\
(1.8018)\end{array}$ & $\begin{array}{r}0.03244 \\
(1.5479)\end{array}$ & $\begin{array}{c}0.02832 \\
(0.7851)\end{array}$ \\
\hline LINC & $\begin{array}{c}0.45906 \\
(11.680)\end{array}$ & $\begin{array}{c}0.44854 \\
(11.273)\end{array}$ & $\begin{array}{c}0.45486 \\
(7.8473)\end{array}$ & $\begin{array}{r}0.41153 \\
(7.1784)\end{array}$ & $\begin{array}{r}0.49181 \\
(7.2585)\end{array}$ \\
\hline$L M T$ & $\begin{array}{l}-0.02853 \\
(-1.0834)\end{array}$ & $\begin{array}{l}-0.02309 \\
(-0.8601)\end{array}$ & $\begin{array}{l}-0.03892 \\
(-1.1209)\end{array}$ & $\begin{array}{l}-0.02420 \\
(-0.7030)\end{array}$ & $\begin{array}{l}-0.02516 \\
(-0.6593)\end{array}$ \\
\hline$L H V R N T$ & $\begin{array}{l}-0.42551 \\
(-4.5920)\end{array}$ & $\begin{array}{l}-0.44957 \\
(-4.7242)\end{array}$ & $\begin{array}{l}-0.60522 \\
(-5.0671)\end{array}$ & $\begin{array}{l}-0.68632 \\
(-5.7380)\end{array}$ & $\begin{array}{l}-0.06880 \\
(-0.50705)\end{array}$ \\
\hline$A G E$ & $\begin{array}{l}0.08006 \\
(10.222)\end{array}$ & $\begin{array}{l}0.08126 \\
(10.133)\end{array}$ & $\begin{array}{c}0.081294 \\
(8.45037)\end{array}$ & $\begin{array}{l}0.082243 \\
(8.5420)\end{array}$ & $\begin{array}{l}0.069052 \\
(5.5234)\end{array}$ \\
\hline$A G E S Q$ & $\begin{array}{l}-0.00052924 \\
(-6.7454)\end{array}$ & $\begin{array}{l}-0.00053302 \\
(-6.6342)\end{array}$ & $\begin{array}{l}-0.00051708 \\
(-5.3134)\end{array}$ & $\begin{array}{l}-0.00050281 \\
(-5.1746)\end{array}$ & $\begin{array}{l}-0.00050042 \\
(-4.0563)\end{array}$ \\
\hline$E D$ & $\begin{array}{c}0.15539 \\
(2.9764)\end{array}$ & $\begin{array}{c}0.15385 \\
(2.8943)\end{array}$ & $\begin{array}{c}0.124150 \\
(1.86633)\end{array}$ & $\begin{array}{r}0.115284 \\
(1.74975)\end{array}$ & $\begin{array}{c}0.22056 \\
(2.90605)\end{array}$ \\
\hline$S E X$ & $\begin{array}{l}-0.2820 \\
(-6.542)\end{array}$ & $\begin{array}{l}-0.29128 \\
(-6.6734)\end{array}$ & $\begin{array}{l}-0.224140 \\
(-3.9462)\end{array}$ & $\begin{array}{l}-0.26223 \\
(-4.7135)\end{array}$ & $\begin{array}{c}-0.29749 \\
(-4.8979)\end{array}$ \\
\hline$R A C E$ & $\begin{array}{l}-0.15901 \\
(-2.5390)\end{array}$ & $\begin{array}{l}-0.16330 \\
(-2.5592)\end{array}$ & $\begin{array}{l}-0.20281 \\
(-2.6955)\end{array}$ & $\begin{array}{l}-0.22382 \\
(-2.9699)\end{array}$ & $\begin{array}{l}-0.05089 \\
(-0.5030)\end{array}$ \\
\hline$M A R R$ & $\begin{array}{c}0.38961 \\
(6.9376)\end{array}$ & $\begin{array}{c}0.39823 \\
(6.9746)\end{array}$ & $\begin{array}{r}0.408757 \\
(5.78570)\end{array}$ & $\begin{array}{c}0.44625 \\
(6.3681)\end{array}$ & $\begin{array}{c}0.26482 \\
(3.2299)\end{array}$ \\
\hline HSIZE & $\begin{array}{c}0.06285 \\
(3.5024)\end{array}$ & $\begin{array}{c}0.06806 \\
(3.7268)\end{array}$ & $\begin{array}{r}0.096073 \\
(4.20085)\end{array}$ & $\begin{array}{c}0.11973 \\
(5.2898)\end{array}$ & $\begin{array}{l}-0.007770 \\
(-0.31515)\end{array}$ \\
\hline CUREMP & $\begin{array}{l}0.007127 \\
(2.6101)\end{array}$ & $\begin{array}{c}0.00703 \\
(2.5469)\end{array}$ & $\begin{array}{c}0.012453 \\
(2.88445)\end{array}$ & $\begin{array}{l}0.012816 \\
(3.0657)\end{array}$ & $\begin{array}{c}0.003480 \\
(1.01094)\end{array}$ \\
\hline$B A D H S T$ & $\begin{array}{c}0.001343 \\
(0.02152)\end{array}$ & $\begin{array}{r}0.00204 \\
(0.0352)\end{array}$ & $\begin{array}{c}0.061162 \\
(0.81257)\end{array}$ & $\begin{array}{c}0.051881 \\
(0.69331)\end{array}$ & $\begin{array}{l}-0.14393 \\
(-1.4303)\end{array}$ \\
\hline WELFARE & $\begin{array}{c}-0.65607 \\
(-8.0226)\end{array}$ & $\begin{array}{l}-0.62946 \\
(-7.4583)\end{array}$ & $\begin{array}{l}-0.72135 \\
(-7.8791)\end{array}$ & $\begin{array}{l}-0.70457 \\
(-7.6345)\end{array}$ & $\begin{array}{l}-0.53431 \\
(-3.0622)\end{array}$ \\
\hline$C C B I G$ & $\begin{array}{l}-0.64139 \\
(-7.4515)\end{array}$ & $\begin{array}{l}-0.66230 \\
(-7.5509)\end{array}$ & $\begin{array}{r}-0.71691 \\
(6.4916)\end{array}$ & $\begin{array}{l}-0.77061 \\
(-6.9101)\end{array}$ & $\begin{array}{l}-0.33249 \\
(-2.3852)\end{array}$ \\
\hline CCOTHER & $\begin{array}{l}-0.26623 \\
(-3.8496)\end{array}$ & $\begin{array}{l}-0.25187 \\
(-3.5842)\end{array}$ & $\begin{array}{l}-0.25495 \\
(-2.8878)\end{array}$ & $\begin{array}{l}-0.20865 \\
(-2.3855)\end{array}$ & $\begin{array}{l}-0.33378 \\
(-3.3038)\end{array}$ \\
\hline$S U B B I G$ & $\begin{array}{l}-0.22822 \\
(-3.0384)\end{array}$ & $\begin{array}{l}-0.22561 \\
(-2.9596)\end{array}$ & $\begin{array}{l}-0.18082 \\
(-1.8283)\end{array}$ & $\begin{array}{c}-0.162386 \\
(-1.66318)\end{array}$ & $\begin{array}{l}-0.32348 \\
(-3.0784)\end{array}$ \\
\hline SUBOTHER & $\begin{array}{l}-0.16632 \\
(-2.4434)\end{array}$ & $\begin{array}{l}-0.16809 \\
(-2.4389)\end{array}$ & $\begin{array}{l}-0.14803 \\
(-1.7061)\end{array}$ & $\begin{array}{c}-0.146954 \\
(-1.71543)\end{array}$ & $\begin{array}{l}-0.22779 \\
(-2.4017)\end{array}$ \\
\hline$F A R S U B$ & $\begin{array}{r}0.13965 \\
(2.0907)\end{array}$ & $\begin{array}{c}0.13293 \\
(1.9668)\end{array}$ & $\begin{array}{c}0.280896 \\
(3.19985)\end{array}$ & $\begin{array}{c}0.26634 \\
(3.1004)\end{array}$ & $\begin{array}{c}-0.012688 \\
(-0.14465)\end{array}$ \\
\hline$\overline{\log } \overline{\mathrm{Lik}} \overline{-}$ & $-31 \overline{54.97}$ & $-\overline{2813.00}$ & $-\overline{1550} \overline{0} \overline{9}$ & $-\overline{159} \overline{1.8}$ & $-12 \overline{7} 2 . \overline{7}$ \\
\hline $\begin{array}{l}\text { Hausman Test }{ }^{\mathrm{a}} \\
\text { Sample }\end{array}$ & 306.689 & 258.417 & - & - & 12 \\
\hline Size & 3569 & 3569 & 3569 & 3569 & 3569 \\
\hline
\end{tabular}

${ }^{\mathrm{a}}$ For the 4-celled ordered probit the Hausman test statistic is distributed $\chi^{2}(60)$ and equals the sum of the three separate Hausman statistics for the Rent 1, Own, and Own 2 models; the Hausman statistics for those models are distributed $\chi^{2}(20)$ and equal $62.3,110.1$, and 134.3, respectively. For the 3 -celled ordered probit the Hausman test statistic is distributed $\chi^{2}(40)$ and equals the sum of the two separate Hausman statistics for the Own and Own2 model; the Hausman statistics for those models are distributed $\chi^{2}(20)$ and equal 106.245 and 152.172 , respectively. 
Table 2a.-Prediction Success for the 4-Celled Ordered and Non-ordered Probit Models

(Ordered probit model numbers are in bold; non-ordered probit model numbers are not in bold)

\begin{tabular}{|c|c|c|c|c|c|}
\hline \multirow[b]{2}{*}{ Actual } & \multicolumn{4}{|c|}{ Predicted Subtenure Choice } & \multirow[b]{2}{*}{ Total } \\
\hline & Rent 1 & Rent 2 & Own1 & Own2 & \\
\hline \multirow[t]{2}{*}{ Rent 1} & 675 & $\mathbf{0}$ & 453 & 1 & 1,129 \\
\hline & 707 & 0 & 420 & 2 & 1,129 \\
\hline \multirow[t]{2}{*}{ Rent 2} & 41 & 0 & 62 & 1 & 104 \\
\hline & 45 & 0 & 59 & 0 & 104 \\
\hline \multirow[t]{2}{*}{ Ownl } & 199 & 0 & 1,532 & 63 & 1,794 \\
\hline & 222 & 0 & 1,536 & 36 & 1,794 \\
\hline \multirow[t]{2}{*}{ Own2 } & 22 & 0 & 460 & 60 & 542 \\
\hline & 31 & 0 & 467 & 44 & 542 \\
\hline \multirow[t]{2}{*}{ Total } & 937 & 0 & 2,507 & 125 & 3,569 \\
\hline & 1,005 & 0 & 2,482 & 82 & 3,569 \\
\hline
\end{tabular}

table 1. A quick review of the table shows that there is an extraordinary degree of similarity across the first four models. For that reason, we focus first on the ordered probit models in columns 1 and 2 . Note that results from the ordered probit models are generally consistent with our priors. The constants, $\alpha_{1}$ and $\alpha_{2}$ are negative, while $\alpha_{3}$ is positive, thus confirming an important feature of the underlying theory of housing subtenure choice. Wealth and income have positive effects of subtenure choice (although wealth is only marginally significant), which suggests that families move progressively from Rent1 towards $O w n 2$ (in figure 1) as wealth and income increase. Although the marginal income tax rate is not significant, the relative cost of owning to renting (proxied by LHVRNT) appears to have a negative and significant effect on the model. Hence, in areas where it is relatively expensive to own, families are more likely to be in a lower subtenure (i.e., closer to Rent1).

Older families ( $A G E$ ), families with more education $(E D=1)$, female headed families $(S E X=$ 0 ), white households $(R A C E=0)$, married families $(M A R R=1)$, and larger households (HSIZE), all are significantly more likely to choose higher subtenure status. A similar finding holds for families that have been on their current job longer (CUREMP) and families that have not recently received welfare payments (WELFARE $=0)$. Interestingly, the location dummy coefficients suggest that as families reside in more densely populated areas, ceteris paribus, they are more likely to choose a lower subtenure classification; the one exception is the FARSUB zone which has a positive effect on subtenure choice relative to rural areas (the omitted category). ${ }^{16}$

Apart from the actual coefficient values in the ordered probit models (which generally seem plausible), as noted above, casual inspection across the models in table 1 shows a striking degree of similarity in coefficient values for nearly all of the regressors except for those of column Own2. In addition, in tables $2 \mathrm{a}$ and $2 \mathrm{~b}$ note that the patterns of predicted subtenures based on the ordered probit models are nearly identical to the patterns of predicted subtenures based on the separate "non-ordered" probit models. These findings suggest that the excess of investment $\left(H_{I}\right)$ over consumption $\left(H_{C}\right)$ demand for housing is both a good predictor and an important determinant of housing subtenure choice.

At the same time, however, observe that the Hausman test statistics (reported at the bottom of table 1) reject the null that the coefficients in the 4- and 3-celled ordered probit models are equal to those of the non-ordered probit models. Hence, based on the more exacting Hausman test, it appears that factors other than the divergence between $H_{I}$ and $H_{C}$ also influence housing subtenure choice. One possible explanation is that tax effects, borrowing constraints, and transactions costs affect housing subtenure choice in a more complicated manner than allowed in the

\footnotetext{
${ }^{16}$ Note, for instance, that the coefficient on $C C B I G$ is substantially less than coefficients on CCOTHER and SUB$B I G$ (which have similar coefficients). Similarly, the coefficients on CCOTHER and SUBBIG are smaller than the coefficient on SUBOTHER which is smaller than the coefficient on FARSUB.
} 


\begin{tabular}{|c|c|c|c|c|}
\hline \multirow[b]{2}{*}{ Actual } & \multicolumn{3}{|c|}{ Predicted Subtenure Choice } & \multirow[b]{2}{*}{ Total } \\
\hline & Rent & Own1 & Own2 & \\
\hline Rent & $\begin{array}{l}745 \\
752\end{array}$ & $\begin{array}{l}486 \\
479\end{array}$ & $\begin{array}{l}2 \\
2\end{array}$ & $\begin{array}{l}\mathbf{1 , 2 3 3} \\
1,223\end{array}$ \\
\hline Own1 & $\begin{array}{l}\mathbf{2 3 1} \\
222\end{array}$ & $\begin{array}{l}\mathbf{1 , 4 9 8} \\
1,536\end{array}$ & $\begin{array}{l}\mathbf{6 5} \\
36\end{array}$ & $\begin{array}{l}\mathbf{1 , 7 9 4} \\
1,794\end{array}$ \\
\hline Own2 & $\begin{array}{l}\mathbf{2 6} \\
31\end{array}$ & $\begin{array}{r}456 \\
467\end{array}$ & $\begin{array}{l}\mathbf{6 0} \\
44\end{array}$ & $\begin{array}{l}\mathbf{5 4 2} \\
542\end{array}$ \\
\hline Total & $\begin{array}{l}\mathbf{1 , 0 0 2} \\
1,005\end{array}$ & $\begin{array}{l}\mathbf{2 , 4 4 0} \\
2,482\end{array}$ & $\begin{array}{r}125 \\
82\end{array}$ & $\begin{array}{l}\mathbf{3 , 5 6 9} \\
3,569\end{array}$ \\
\hline
\end{tabular}

ordered probit models. Another possibility is that housing tenure could enter directly into the household's utility function. ${ }^{17}$

As discussed earlier, in principle two step methods can be used to estimate the investment and consumption demand functions based on OWN2 households controlling for selection effects. Similarly, the "mixed" and "traditional" demand functions can be estimated using $O W N 1$ families and all owner-occupiers (OWN1 plus $O W N 2$ ), respectively, also controlling for selection effects. In practice, however, if the deviation between $H_{I}$ and $H_{C}$ is the principal determinant of housing subtenure choice, then there is no theoretical basis for including variables in the first stage probit models that do not otherwise appear in the demand functions. Under these conditions, identification of the Mills ratio terms in the demand functions relies on the nonlinearity of the probit models. This is problematic, however, because the true degree of nonlinearity in the demand functions is itself unknown. ${ }^{18}$ These problems may account for why the Mills ratio terms in all of the demand functions (investment, consumption, mixed, and traditional) were insignificant and had little effect on the other coefficients in the models. (as in most housing

\footnotetext{
${ }^{17}$ A different explanation is that the large sample size used in calculating the Hausman test causes even small differences across models to appear statistically significant. However, careful review of table 1 reveals sizable differences between estimates from the $O W N 2$ model and the other probit mod-

${ }_{18}^{\text {els. }}$ This problem, of course, is not unique to this study but is endemic to all housing demand studies (see Rosen (1979, 1985), for example).
}

demand studies). In addition, the absence of exclusion restrictions could explain why the full maximum likelihood model described in appendix A failed to converge. Accordingly, to conserve space table 3 presents results only from the OLS demand functions even though the OLS models may suffer from sample selection effects (two-step results are provided in Ioannides and Rosenthal (1991)). ${ }^{19}$

In table 3 observe that $X^{2}$ tests soundly reject the null that the coefficients in the investment $\left(H_{I}\right)$ and consumption $\left(H_{C}\right)$ functions are alike which indicates that $H_{I}$ and $H_{C}$ do in general deviate from one another. ${ }^{20}$ Additional $X^{2}$ tests fail to reject the null that the coefficients in the mixed function differ from either the consumption function or the traditional demand function. ${ }^{21}$ These findings suggest that Own1 housing levels are determined primarily by the consumption demand for housing, not portfolio motives. An important implication of this result is that previous empirical studies of housing demand likely have identified the consumption demand for housing since those studies estimate the traditional demand function.

Given these test results, a comparison of the investment and consumption functions is most

\footnotetext{
${ }^{19}$ Relative to the estimates in table 3 , the principal effect of including the Mills ratios was to increase the standard errors on the other coefficients but not enough to change the nature of our findings.

${ }^{20}$ The relevant test statistic equals 350.24 compared to a critical value (at the $5 \%$ level) of 31.4 .

${ }^{21}$ The test statistic comparing the "mixed" and "traditional" demand functions equals 16.33 compared to a critical value (at the 5\% level) of 31.4 .
} 
Table 3.-Ordinary Least Souares Housing Demand Functions (numbers in parentheses are $t$-ratios)

\begin{tabular}{|c|c|c|c|c|}
\hline Variable & Investment $^{\mathrm{a}}$ & Consumption $^{\mathrm{a}}$ & Mixed $^{\mathrm{a}}$ & Traditional $^{\mathrm{a}}$ \\
\hline Constant & $\begin{array}{c}0.098496 \\
(0.119627)\end{array}$ & $\begin{array}{c}-1.034657 \\
(-1.378055)\end{array}$ & $\begin{array}{c}-1.521006 \\
(-3.361093)\end{array}$ & $\begin{array}{c}-1.461329 \\
(-3.783468)\end{array}$ \\
\hline$W H A T$ & $\begin{array}{c}0.110547 \\
(2.157215)\end{array}$ & $\begin{array}{c}0.052031 \\
(1.113432)\end{array}$ & $\begin{array}{c}0.005650 \\
(0.341547)\end{array}$ & $\begin{array}{c}0.012570 \\
(0.820111)\end{array}$ \\
\hline LINC & $\begin{array}{c}0.542004 \\
(7.421187)\end{array}$ & $\begin{array}{c}0.456025 \\
(6.847310)\end{array}$ & $\begin{array}{c}0.386404 \\
(10.745894)\end{array}$ & $\begin{array}{c}0.411058 \\
(13.285273)\end{array}$ \\
\hline$L M T$ & $\begin{array}{c}-0.034813 \\
(-0.909851)\end{array}$ & $\begin{array}{c}-0.042754 \\
(-1.225378)\end{array}$ & $\begin{array}{c}-0.054921 \\
(-2.594874)\end{array}$ & $\begin{array}{l}-0.051790 \\
(-2.869955)\end{array}$ \\
\hline$L H V R N T$ & $\begin{array}{c}0.859911 \\
(6.278528)\end{array}$ & $\begin{array}{c}0.846369 \\
(6.776793)\end{array}$ & $\begin{array}{c}0.810149 \\
(10.147730)\end{array}$ & $\begin{array}{c}0.821890 \\
(12.208861)\end{array}$ \\
\hline$A G E$ & $\begin{array}{c}0.015575 \\
(1.113444)\end{array}$ & $\begin{array}{c}0.031877 \\
(2.499121)\end{array}$ & $\begin{array}{c}0.047776 \\
(7.411003)\end{array}$ & $\begin{array}{c}0.045952 \\
(8.070296)\end{array}$ \\
\hline$A G E S Q$ & $\begin{array}{c}-0.000068 \\
(-0.507550)\end{array}$ & $\begin{array}{c}-0.000242 \\
(-1.968274)\end{array}$ & $\begin{array}{c}-0.000399 \\
(-6.321894)\end{array}$ & $\begin{array}{c}-0.000378 \\
(-6.784153)\end{array}$ \\
\hline$E D$ & $\begin{array}{c}0.182431 \\
(2.301886)\end{array}$ & $\begin{array}{c}0.234246 \\
(3.24189)\end{array}$ & $\begin{array}{c}0.314476 \\
(7.786161)\end{array}$ & $\begin{array}{c}0.299730 \\
(8.540773)\end{array}$ \\
\hline$S E X$ & $\begin{array}{c}0.088788 \\
(1.471916)\end{array}$ & $\begin{array}{c}0.059863 \\
(1.088287)\end{array}$ & $\begin{array}{c}-0.068823 \\
(-1.990656)\end{array}$ & $\begin{array}{c}-0.043817 \\
(-1.503412)\end{array}$ \\
\hline$R A C E$ & $\begin{array}{c}-0.345314 \\
(-3.0167348)\end{array}$ & $\begin{array}{c}-0.288861 \\
(-2.767048)\end{array}$ & $\begin{array}{r}-0.286980) \\
(-5.488167)\end{array}$ & $\begin{array}{c}-0.281374 \\
(-6.055243)\end{array}$ \\
\hline$M A R R$ & $\begin{array}{c}-0.076279 \\
(-0.850350)\end{array}$ & $\begin{array}{c}-0.043069 \\
(-0.526518)\end{array}$ & $\begin{array}{c}-0.019928 \\
(-0.450283)\end{array}$ & $\begin{array}{c}-0.030867 \\
(-0.797561)\end{array}$ \\
\hline HSIZE & $\begin{array}{c}-0.007547 \\
(-0.271911)\end{array}$ & $\begin{array}{c}0.013073 \\
(0.516486)\end{array}$ & $\begin{array}{c}0.048708 \\
(3.759652)\end{array}$ & $\begin{array}{c}0.042870 \\
(3.750116)\end{array}$ \\
\hline CUREMP & $\begin{array}{c}-0.008842 \\
(-2.691325)\end{array}$ & $\begin{array}{c}-0.005336 \\
(-1.781223)\end{array}$ & $\begin{array}{c}0.000687 \\
(0.332868)\end{array}$ & $\begin{array}{c}-0.000960 \\
(-0.562360)\end{array}$ \\
\hline$B A D H S T$ & $\begin{array}{c}0.004760 \\
(0.040824)\end{array}$ & $\begin{array}{c}-0.097766 \\
(-0.919429)\end{array}$ & $\begin{array}{c}-0.072167 \\
(-1.449990)\end{array}$ & $\begin{array}{c}-0.077785 \\
(-1.738814)\end{array}$ \\
\hline WELFARE & $\begin{array}{c}0.022353 \\
(0.086481)\end{array}$ & $\begin{array}{c}-0.000325 \\
(-0.001379)\end{array}$ & $\begin{array}{c}-0.553305 \\
(-7.812240)\end{array}$ & $\begin{array}{c}-0.518568 \\
(-7.809635)\end{array}$ \\
\hline$C C B I G$ & $\begin{array}{c}-0.123914 \\
(-0.813558)\end{array}$ & $\begin{array}{c}-0.126997 \\
(-0.914365)\end{array}$ & $\begin{array}{c}0.038815 \\
(0.442388)\end{array}$ & $\begin{array}{c}-0.004157 \\
(-0.056076)\end{array}$ \\
\hline CCOTHER & $\begin{array}{c}-0.055594 \\
(-0.538297)\end{array}$ & $\begin{array}{c}-0.010620 \\
(-0.112764)\end{array}$ & $\begin{array}{c}0.030108 \\
(0.540863)\end{array}$ & $\begin{array}{c}0.020733 \\
(0.434113)\end{array}$ \\
\hline$S U B B I G$ & $\begin{array}{c}-0.037729 \\
(-0.364397)\end{array}$ & $\begin{array}{c}0.151462 \\
(1.604235)\end{array}$ & $\begin{array}{c}0.146411 \\
(2.439690)\end{array}$ & $\begin{array}{c}0.142154 \\
(2.811015)\end{array}$ \\
\hline SUBOTHER & $\begin{array}{c}-0.034501 \\
(-0.364532)\end{array}$ & $\begin{array}{c}0.086520 \\
(1.002483)\end{array}$ & $\begin{array}{c}-0.010247 \\
(-0.191462)\end{array}$ & $\begin{array}{c}0.006331 \\
(0.139280)\end{array}$ \\
\hline$F A R S U B$ & $\begin{array}{c}-0.115215 \\
(-1.342660)\end{array}$ & $\begin{array}{c}-0.046280 \\
(-0.591437)\end{array}$ & $\begin{array}{c}-0.081680 \\
(-1.664010)\end{array}$ & $\begin{array}{c}-0.075760 \\
(-1.812547)\end{array}$ \\
\hline $\bar{R} \overline{2}(\overline{\mathrm{adj}} . \overline{)}$ &.$\overline{378}$ & .387 & .399 & .413 \\
\hline $\begin{array}{l}\sigma \\
\rho^{\prime} \rho^{\mathrm{b}}\end{array}$ & .651 & .593 & .660 & .646 \\
\hline$e^{\prime} e^{\mathrm{b}}$ & 221.1 & 183.8 & 773.7 & 966.4 \\
\hline $\begin{array}{l}\chi^{2} \text { Test }^{\mathrm{c}} \\
F \text {-statistic }\end{array}$ & 350.24 & 23.88 & - & 16.33 \\
\hline$F$-statistic & 18.30 & 18.99 & 63.54 & 87.49 \\
\hline Sample Size & 542 & 542 & 1794 & 2336 \\
\hline
\end{tabular}

${ }^{a}$ The investment and consumption demand functions were estimated over the Own 2 households. The mixed and traditional demand functions were estimated over the $O w n 1=1$ households and all owner-occupiers $($ Own $1=$ Own2 = 1), respectively. The dependent variable for the investment function was the log of the total value of all real estate holdings (including the primary home). The dependent variable for the remaining functions was the log of the principal residence value.

${ }^{\mathrm{b}}$ Sum of squared residuals.

Sum of squared residuals.
All $\chi^{2}$-test statistics are distributed Chi-square with 20 degrees of freedom and are constructed relative to the mixed function. For the investment and consumption functions, the parameters are estimated over different subsets of the sample (relative to the mixed function) which ensures that the estimated coefficients are independent across models. Hence, $\left(q_{m}-q_{t}\right)^{\prime}\left[V_{m}+V_{t}\right]^{-1}\left(q_{m}-q_{t}\right)$ is the appropriate test statistic, where $q_{m}$ and $q_{t}$ are the parameters from the mixed and alternative functions (Investment or Consumption), respectively, while $V_{m}$ and $V_{t}$ are the corresponding covariance matrices. A Hausman test is used to compare the traditional and mixed models as described in the text. 
accurately obtained based on the traditional demand function (since the traditional function uses more data than the $O w n 2$ consumption and $O w n 1$ mixed functions and is, therefore, more efficient). Comparing the investment and traditional functions, note that, although both increase with wealth and income, investment demand is more sensitive to changes in these variables. In addition, wealth and income are both significant in the investment function, while only income is significant in the consumption equation. In contrast, age, education, and household size ( $H S I Z E)$ all have positive and significant effects on the consumption demand for housing, but have smaller and generally not significant coefficients in the investment model. Race effects across the two models appear to be similar, as are price effects as proxied by $L M T$ and $L H V R N T$. Location further proxies price effects (by reflecting regional differences in housing prices), but proximity to different urban zones appears to have little effect on investment demand, which may reflect that real estate investment is not necessarily tied to a family's immediate area of residence. In contrast, consumption demand apparently is sensitive to location, as suggested by the positive and significant coefficient on $S U B B I G$ and the negative and (marginally) significant coefficient on FARSUB. ${ }^{22}$

\section{Conclusions}

Theoretical work by Henderson and Ioannides (1983) suggests that in the absence of tax distortions, borrowing constraints, and transactions costs, the decision to own a home is driven by the divergence between the investment $\left(H_{I}\right)$ and consumption $\left(H_{C}\right)$ demands for housing (see also $\mathrm{Fu}$ (1991)). Using the 1983 Survey of Consumer Finances, this paper tests that theory by distinguishing four housing subtenures. Families can rent without owning property, rent while owning property other than their home, own their home without owning other properties, or own their home

\footnotetext{
${ }^{22}$ Although receiving welfare payments appears to have a much stronger negative effect on consumption demand than on investment demand, the insignificant coefficient of $W E L$ $F A R E$ in the investment model could reflect the relatively small number of $O w n 2$ families that receive welfare (which would make it difficult to identify the corresponding coefficient).
}

in addition to other properties. Provided the assumptions underlying the Henderson and Ioannides (1983) model are met, choice of housing subtenure is based on an ordered probit model in which the underlying latent index equals the excess of the investment demand over the consumption demand for housing, $H_{I}$ minus $H_{C}$. We argue that this model can also be generalized to allow for the effect of tax distortions and the like by omitting the distinction between Rent 1 and Rent 2 families and focusing on the divergence between $H_{I}$ and $H_{C}$ that would arise when families face the budget space enjoyed by owneroccupiers.

If the divergence between $H_{I}$ and $H_{C}$ is the sole determinant of housing subtenure choice, then a series of separate non-ordered probit models for different subtenure classifications yield consistent but inefficient estimates of the model parameters. On the one hand, the non-ordered probit models yield a set of estimated coefficients and pattern of predicted subtenures that is remarkably close to the ordered probit models. This finding confirms that the excess of investment over consumption demand for housing is an important determinant of housing subtenure choice. However, a more exacting Hausman test rejects the structure implied by the ordered probit model which indicates that factors other than the divergence between $H_{I}$ and $H_{C}$ also affect housing subtenure. One possible explanation for this finding could be that housing tenure status enters directly into household utility functions. Another possibility is that tax effects, borrowing constraints, and transactions costs affect housing subtenure choice in a more complicated manner than allowed for in the ordered probit models.

A second important contribution of this paper is that we separately identify the housing investment and consumption demand functions by focusing on households that own both their principal residence and additional real estate. Regression results confirm that the investment and consumption demands for housing differ. Specifically, the investment demand for housing is more sensitive to wealth and income than is the consumption demand for housing, but consumption demand is more sensitive to demographic variables like age, education, and family size, as well as proximity to urban centers. Test results also 
strongly indicate that the residence of most owner-occupiers is determined primarily by their consumption demand for housing, not their investment demand. An important implication of this result is that previous empirical studies of housing demand likely have identified the consumption demand for housing given that those studies typically do not distinguish between housing investment and consumption.

\section{APPENDIX A}

\section{Likelihood Function for the Complete Model}

This appendix presents the likelihood function for the complete model based on the 4-celled subtenure framework. For Rent 1 households the contribution to the likelihood function is

$$
\begin{aligned}
L_{\text {Rentl }} & =\operatorname{Pr}\left[e_{I}-e_{C}<\alpha_{1}-X\left(b_{I}-b_{C}\right)\right] \\
& =F\left\{\left[\alpha_{1}-X\left(b_{I}-b_{C}\right)\right] / \sigma_{w}\right\}
\end{aligned}
$$

where $\sigma_{w}^{2}=\sigma_{I}^{2}+\sigma_{C}^{2}-2 \sigma_{I C}$ and $F$ is the unit normal distribution function. For Rent 2 households the contribution to the likelihood function is

$$
\begin{gathered}
L_{\text {Rent } 2}=\operatorname{Pr}\left[e_{I}=H_{I}-X b_{I}, \quad \alpha_{1}-X\left(b_{I}-b_{C}\right)\right. \\
\left.<e_{I}-e_{C}<\alpha_{2}-X\left(b_{I}-b_{C}\right)\right] \\
=\left\{F \left\{\left[-\alpha_{1}+\left(1-\sigma_{I C} / \sigma_{I}^{2}\right) H_{I}\right.\right.\right. \\
\left.+X\left(b_{I} \sigma_{I C} / \sigma_{I}^{2}-b_{C}\right)\right] / \sigma_{v} \\
-F\left\{\left[-\alpha_{2}+\left(1-\sigma_{I C} / \sigma_{I}^{2}\right) H_{I}\right.\right. \\
\left.\left.+X\left(b_{I} \sigma_{I C} / \sigma_{I}^{2}-b_{C}\right)\right] / \sigma_{v}\right\} \\
\cdot f\left\{\left(H_{I}-X b_{I}\right) / \sigma_{I}\right\},
\end{gathered}
$$

where $\sigma_{v}=\left(\sigma_{C}^{2}-\sigma_{I C}^{2} / \sigma_{I}^{2}\right)^{1 / 2}, f(\cdot)$ is the unit normal density, and we condition on $e_{I}$ such that, $e_{C} \mid e_{I} \sim$ $N\left(e_{I} \sigma_{I C} / \sigma_{I}^{2}, \sigma_{v}^{2}\right)$. For Own1 families the contribution to the likelihood is given by

$$
\begin{aligned}
L_{O w n I}= & \operatorname{Pr}\left[\alpha_{3}-X\left(b_{I}-b_{C}\right)<e_{I}-e_{c}<\alpha_{2}\right. \\
& \left.-X\left(b_{I}-b_{C}\right)\right] \\
= & F\left\{\left[\alpha_{3}-X\left(b_{I}-b_{C}\right)\right] / \sigma_{w}\right\} \\
& -F\left\{\left[\alpha_{2}-X\left(b_{I}-b_{C}\right)\right] / \sigma_{w}\right\},
\end{aligned}
$$

and for Own2 households the contribution to the likelihood is,

$$
\begin{aligned}
L_{O w n 2}= & \operatorname{Pr}\left[e_{I}=H_{I}-X b_{I}, e_{C}=H_{C}-X b_{C}\right] \\
= & f\left\{\left[H_{C}-H_{I} \sigma_{I C} / \sigma_{I}^{2}+X\left(b_{I} \sigma_{I C} / \sigma_{I}^{2}-b_{C}\right)\right] / \sigma_{r}\right\} \\
& \cdot f\left\{\left(H_{I}-X b_{I}\right) / \sigma_{I}\right\} .
\end{aligned}
$$

\section{APPENDIX B}

\section{Variable Definitions and Summary Statistics (all monetary values are in 1982 dollars)}

$H_{I}$ equals the $\log$ of the value of a family's total real estate holdings residence (in 1,000 dollar units).

$H_{C}$ equals the log of the value of a family's primary residence if they own their home (in 1,000 dollar units).

Own equals 1 if the household owns their home in 1983 and 0 otherwise.

Own1 equals 1 if the household owns their home in 1983 but does not own other property, and 0 otherwise.

Own 2 equals 1 if the household owns their home in 1983 as well as other property, and 0 otherwise.

Rent 2 equals 1 if the household does not own their home in 1983 but owns other property, and 0 otherwise.

Rent 1 equals 1 if the household does not own their home in 1983 or other property, and 0 otherwise.

Wealth equals 1982 household net worth (nonpension assets minus debt) in 100,000 dollars units. WHAT equals log of the fitted value from the Wealth regression (see the text for further details).

$I N C$ equals total household income in 1982 dollars $(100,000$ dollar units). $L I N C$ equals $\log$ of $I N C$.

$L M T$ equals $\log$ of the family's Federal marginal income tax rate.

LHVRNT equals the log ratio of the county-wide median house value to the county-wide median monthly rent based on the household's county in 1980 .

$A G E$ equals the age of the household head. $A G E S Q$ equals $A G E$ squared.

$E D$ equals 1 if the household head has a high school degree or more. SEX equals 1 if the head is male.

$R A C E$ equals 1 if the household head is nonwhite. MARR equals 1 if married. $H S I Z E$ equals the number of people in the household.

CUREMP equals the number of years working at current employer.

$B A D H S T$ equals 1 if the household had problems making loan payments in the last three years.

WELFARE equals 1 if the household received public assistance in 1982.

$C C B I G$ equals 1 if in the central cities of one of the ten largest SMSAs. CCOTHER equals 1 if in the central cities of SMSAs other than those included in $C C B I G$.

$S U B B I G$ equals 1 if in the suburbs of one of the ten largest SMSAs; SUBOTHER equals 1 if in the suburbs of SMSAs; not included in SUBBIG.

FARSUB equals 1 if outside the suburban belt but within 50 miles of a central business district. 
Table B.1.-Summary Statistics

(values above parentheses are sample means; values in the parentheses are standard deviations)

\begin{tabular}{|c|c|c|c|c|c|}
\hline Variable & Full Sample & Own2 & Own1 & Rent2 & Rent1 \\
\hline Sample Size & 3569 & 542 & 1794 & 104 & 1129 \\
\hline \multirow[t]{2}{*}{$O W N$} & 0.6545 & - & - & - & - \\
\hline & $(0.4756)$ & - & - & - & - \\
\hline \multirow[t]{2}{*}{$O W N 2$} & 0.1519 & - & - & - & - \\
\hline & $(0.3589)$ & - & - & - & - \\
\hline \multirow[t]{2}{*}{ OWN1 } & 0.5027 & - & - & - & - \\
\hline & $(0.5001)$ & - & - & - & - \\
\hline \multirow[t]{2}{*}{ RENT2 } & 0.0291 & - & - & - & - \\
\hline & $(0.1682)$ & - & - & - & - \\
\hline \multirow[t]{2}{*}{ RENT1 } & 0.3163 & - & - & - & - \\
\hline & $(0.4651)$ & - & - & - & - \\
\hline \multirow[t]{2}{*}{$H_{C}$} & 0.1194 & 4.0915 & 3.7490 & - & - \\
\hline & $(5.1514)$ & $(0.7581)$ & $(0.8516)$ & - & - \\
\hline \multirow[t]{2}{*}{$H_{I}$} & 0.4957 & 4.6261 & - & 3.2207 & - \\
\hline & $(5.0989)$ & $(0.8252)$ & - & (1.4141) & - \\
\hline \multirow[t]{2}{*}{$W E A L T H$} & 0.7495 & 1.8690 & 0.8305 & 0.7165 & 0.0863 \\
\hline & $(1.2258)$ & (1.7893) & $(1.1225)$ & $(0.9655)$ & $(0.2769)$ \\
\hline \multirow[t]{2}{*}{$I N C$} & 0.2479 & 0.3822 & 0.2657 & 0.2490 & 0.1551 \\
\hline & $(0.2413)$ & $(0.2793)$ & $(0.2493)$ & $(0.1882)$ & $(0.1643)$ \\
\hline \multirow[t]{2}{*}{$M T$} & 0.1640 & 0.2276 & 0.1716 & 0.1796 & 0.1199 \\
\hline & $(0.1261)$ & $(0.1325)$ & $(0.1260)$ & $(0.1216)$ & $(0.1062)$ \\
\hline \multirow[t]{2}{*}{ LHVRNT } & 5.2925 & 5.2888 & 5.2641 & 5.3541 & 5.3337 \\
\hline & $(0.2316)$ & $(0.2226)$ & $(0.2134)$ & $(0.2743)$ & $(0.2517)$ \\
\hline \multirow[t]{2}{*}{$A G E$} & 45.7506 & 50.7343 & 48.9415 & 39.2692 & 38.8849 \\
\hline & (17.1774) & (14.2015) & (16.5493) & (14.9914) & (17.3652) \\
\hline \multirow[t]{2}{*}{$E D$} & 0.7117 & 0.8026 & 0.6895 & 0.7981 & 0.6953 \\
\hline & $(0.4530)$ & $(0.3984)$ & $(0.4628)$ & $(0.4034)$ & $(0.4605)$ \\
\hline \multirow[t]{2}{*}{$S E X$} & 0.5133 & 0.4871 & 0.5279 & 0.6058 & 0.4942 \\
\hline & $(0.4999$ & $(0.5003)$ & $(0.4994)$ & $(0.4911)$ & $(0.5002)$ \\
\hline \multirow[t]{2}{*}{$R A C E$} & 0.1561 & 0.0756 & 0.1176 & 0.1635 & 0.2551 \\
\hline & $(0.3630)$ & $(0.2647)$ & $(0.3222)$ & $(0.3716)$ & $(0.4361)$ \\
\hline \multirow[t]{2}{*}{$M A R R$} & 0.6153 & 0.7915 & 0.7068 & 0.5000 & 0.3959 \\
\hline & $(0.4866)$ & $(0.4066)$ & $(0.4554)$ & $(0.5024)$ & $(0.4893)$ \\
\hline \multirow[t]{2}{*}{ HSIZE } & 2.7150 & 2.8893 & 2.9091 & 2.3077 & 2.3605 \\
\hline & (1.5242) & $(1.3468)$ & (1.5236) & (1.5013) & $(1.5386)$ \\
\hline \multirow[t]{2}{*}{ CUREMP } & 5.4651 & 7.9225 & 6.2402 & 4.8750 & 3.1081 \\
\hline & (8.0789) & (9.7137) & (8.6699) & (6.0974) & $(5.3732)$ \\
\hline \multirow[t]{2}{*}{$B A D H S T$} & 0.1292 & 0.0701 & 0.1282 & 0.1538 & 0.1568 \\
\hline & $(0.3354)$ & $(0.2556)$ & $(0.3344)$ & $(0.3625)$ & $(0.3638)$ \\
\hline \multirow[t]{2}{*}{ WELFARE } & 0.1082 & 0.0129 & 0.0602 & 0.0673 & 0.02338 \\
\hline & $(0.3106)$ & $(0.1130)$ & $(0.2379)$ & $(0.2518)$ & $(0.4235)$ \\
\hline$C C B I G$ & 0.0855 & 0.0498 & 0.0418 & 0.1442 & 0.1665 \\
\hline & $(0.2796)$ & $(0.2178)$ & $(0.2002)$ & $(0.3530)$ & $(0.3727)$ \\
\hline CCOTHER & 0.1802 & 0.1365 & 0.1695 & 0.1442 & 0.2214 \\
\hline & $(0.3844)$ & $(0.3437)$ & $(0.3753)$ & $(0.3530)$ & $(0.4154)$ \\
\hline$S U B B I G$ & 0.1407 & 0.1550 & 0.1438 & 0.1538 & 0.1275 \\
\hline & $(0.3477)$ & $(0.3622)$ & $(0.3510)$ & $(0.3625)$ & $(0.3337)$ \\
\hline SUBOTHER & 0.1978 & 0.1937 & 0.1996 & 0.2308 & 0.1940 \\
\hline & $(0.3984)$ & $(0.3956)$ & $(0.3998)$ & $(0.4234)$ & $(0.3956)$ \\
\hline FARSUB & 0.2303 & 0.2768 & 0.2815 & 0.1923 & 0.1302 \\
\hline & $(0.4211)$ & $(0.4478)$ & $(0.4499)$ & $(0.3960)$ & $(0.3367)$ \\
\hline
\end{tabular}




\section{REFERENCES}

Amemiya, Takeshi, Advanced Econometrics (Cambridge: Harvard University Press, 1985).

Avery, Robert B., and Gregory E. Elliehausen, “1983 Survey of Consumer Finances: Technical Manual and Codebook," Federal Reserve Board, Aug. 1988.

Boyes, W. J., D. L., Hoffman, and S. A. Low, "An Econometric Analysis of the Bank Credit Scoring Problem," Journal of Econometrics 40 (Jan. 1989), 3-14.

Duca, John V., and Stuart S. Rosenthal, "Borrowing Constraints and Access to Owner-Occupied Housing," Regional Science and Urban Economics (forthcoming).

, "Borrowing Constraints, Household Debt, and Racial Discrimination in Loan Markets," unpublished mimeo, University of British Columbia (1993).

Fu, Yuming, "A Model of Housing Tenure Choice: Comment," American Economic Review 81 (1991), 381-383.

Goodman, Allen, "Modelling and Computing Transactions Costs for Purchasers of Housing Services," AREUEA Journal 18 (1990), 1-21.

$\rightarrow$ Henderson, J. Vernon, and Yannis M. Ioannides, "A Model of Housing Tenure Choice," American Economic Review 73 (1983), 98-113.

Henderson, J. Vernon, and Yannis M. Ioannides, "OwnerOccupancy: Investment vs. Consumption Demand," Journal of Urban Economics 21 (1987), 228-241.

Ioannides, Yannis M., and Stuart S. Rosenthal, "Econometric Identification of Consumption and Investment Demands for Housing and Their Effect on Housing Tenure Status," University of British Columbia working paper \#91-ULE-007, Faculty of Commerce and Business Administration (Sept. 1991).
Internal Revenue Service, "Individual Tax Model File," Office of Tax Policy Research, School of Business, University of Michigan, various years.

Jappelli, T., Who Is Credit Constrained in the U.S."? Quarterly Journal of Economics 105 (Feb. 1990), 219-234.

Maddala, G. S., Limited-Dependent and Qualitative Variables in Econometrics (New York: Cambridge University Press, 1983).

Munnell, A. H., L. E. Brown, J. McEneaney, and G. Tootell, "Mortgage Lending in Boston: Interpreting the HMDA Data," Federal Reserve Bank of Boston Working Paper Series No. $92-7$ (Oct. 1992).

Olsen, Edgar, "The Demand and Supply of Housing Service: A Critical Survey of the Empirical Literature," in E. S. Mills (ed.), Handbook of Regional and Urban Economics 2 (Amsterdam: Elsevier Science Publishers, North-Holland, 1987), 989-1022.

Rosen, Harvey, "Housing Decisions and the U.S. Income Tax: An Econometric Analysis," Journal of Public Economics 88 (1979). , "Housing Subsidies: Effects of Housing Decisions, Efficiency, and Equity," in A. Auerbach and M. Feldstein (eds.), Handbook of Public Economics, 1 (Amsterdam: Elsevier Science Publishers, North-Holland, 1985) 375-420.

Venti, Steven, and David Wise, "Moving and Housing Expenditure: Transactions Costs and Disequilibrium," Journal of Public Economics 23 (1984), 207-243.

Zorn, Peter, "Mobility-Tenure Decisions and Financial Credit: Do Mortgage Qualification Requirements Constrain Home Ownership?" AREUEA Journal 17 (Spring 1989), $1-16$. 